\title{
Setting of Causes of Adhesive Bonds Destruction by Means of Optical Analysis
}

Miroslav Müller

Faculty of Engineering, Czech University of Life Sciences Prague. Czech Republic. E-mail: muller@tt.czu.cz.

A research analyses an influence of an adhesive surface treatment on an adhesive bond strength. Constructional adhesives used for bonding in an automotive industry were used for the research. A significant factor for evaluating the adhesive bond failure is the research of bonded areas by means of an optical analysis. An even layer of the adhesive in the bond is connected with it. The adhesive bonds diagnostics is difficult. It is necessary to control a quality of the production at the production process. A significant factor lowering the resultant strength of the adhesive bond is its creation. One of possibilities of the adhesive bond diagnostics is to use a method of an optical analysis. An uneven layer of the adhesive belongs among main causes of a failure / considerable decrease of the strength of the adhesive bond.

Keywords: Adhesive layer, Diagnostic, Failure area, One-component epoxy, testing

\section{Acknowledgement}

This paper has been done when solving the grant IGA TF (No.: 2014:31140/1312/3133).

\section{References}

[1] MÜLlER, M., CHOTĚBORSKÝ, R., KRMELA, J. (2007). Technological and constructional aspects affecting bonded joints. In: Research in Agricultural Engineering, Vol. 53, pp. 67-74.

[2] MÜLLER, M., VALÁŠEK, P. (2013). Assessment of bonding quality for several commercially available adhesives . In: Agronomy Research, Vol. 11, No. 1, pp. 155-162.

[3] CIDLINA, J., MÜLlER, M., VALÁŠEK, P. (2014). Evaluation of Adhesive Bond Strength Depending on Degradation Type and Time. In: Manufacturing Technology, Vol. 14, No. 1, pp. 8-12.

[4] NOVÁK, M. (2012). Surfaces with high precision of roughness after grinding. In: Manufacturing technology, Vol. 12 , pp. $66-70$

[5] NOVÁK, M. (2011). Surface quality of hardened steels after grinding. In: Manufacturing technology, Vol. 11, pp.55-59.

[6] HOLEŠOVSKÝ, F., NÁPRSTKOVÁ, N., NOVÁK, M. (2012). GICS for grinding process optimization. In: Manufacturing technology, Vol. 12, pp. 22-26.

[7] MESSLER, R. W. (2004). Joining of materials and structures from pragmatic process to enabling technology. Burlington: Elsevier, 790 p.

[8] MÜLLER, M. (2013). Research of renovation possibility of machine tools damage by adhesive bonding technology. In: Manufacturing Technology, Vol. 13, pp. 504-509.

[9] MÜLLER, M. (2014). Influence of adhesives storing temperature on adhesive bond strength. In: Manufacturing Technology, Vol. 14, pp. 71-75.

[10] MÜLLER, M. (2013). Research of Liquid Contaminants Influence on Adhesive Bond Strength Applied in Agricultural Machine Construction. In: Agronomy Research, Vol.11, pp. 147-154.

[11] MÜLLER, M. (2011). Influence of Surface Integrity on Bonding Process. In: Research in Agricultural Engineering, Vol. 57, pp. 153-162.

[12] RUDAWSKA, A. (2014). Selected aspects of the effect of mechanical treatment on surface roughness and adhesive joint strength of steel sheets. In: International Journal of Adhesion and Adhesives, Vol. 50, pp. 235-243.

[13] NAITO, K., ONTA, M., KOGO, Y. (2012). The Effect of Adhesive Thickness on Tensile and Shear Strength of Polyimide Adhesive. In: International Journal of Adhesion \& Adhesives, Vol. 36, pp. 77-85.

[14] COMYN, J. (1990). Surface treatment and analysis for adhesive bonding. In: International Journal of Adhesion $\&$ Adhesives, Vol. 10, p. 161-165.

[15] KOTOUSOV, A. (2007). Effect of a thin plastic adhesive layer on the stress singularities in a bi-material wedge. In: International Journal of Adhesion \& Adhesives, Vol. 27, No. 8, pp. 647-652. 
[16] GRANT, L. D. R. et al., (2009). Experimental and numerical analysis of single-lap joints for the automotive industry. In: International Journal of Adhesion \& Adhesives, Vol. 29, No. 4, pp. 405-413.

[17] OLIA, M., ROSSETTOS, J. N., (1996). Analysis of adhesively bonded joints with gaps subjected to bending. In: International Journal of Solids and Structures, Vol. 33, No. 18, pp. 2681-2693.

\section{Paper number: M201468}

Copyright (C) 2014. Published by Manufacturing Technology. All rights reserved. 